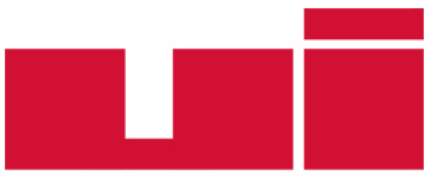

ULLUSLARARASIILIŞKiLER
Akademik Dergi

Yayın ilkeleri, izinler ve abonelik hakkında ayrıntılı bilgi:

E-mail: bilgi@uidergisi.com

Web: www.uidergisi.com

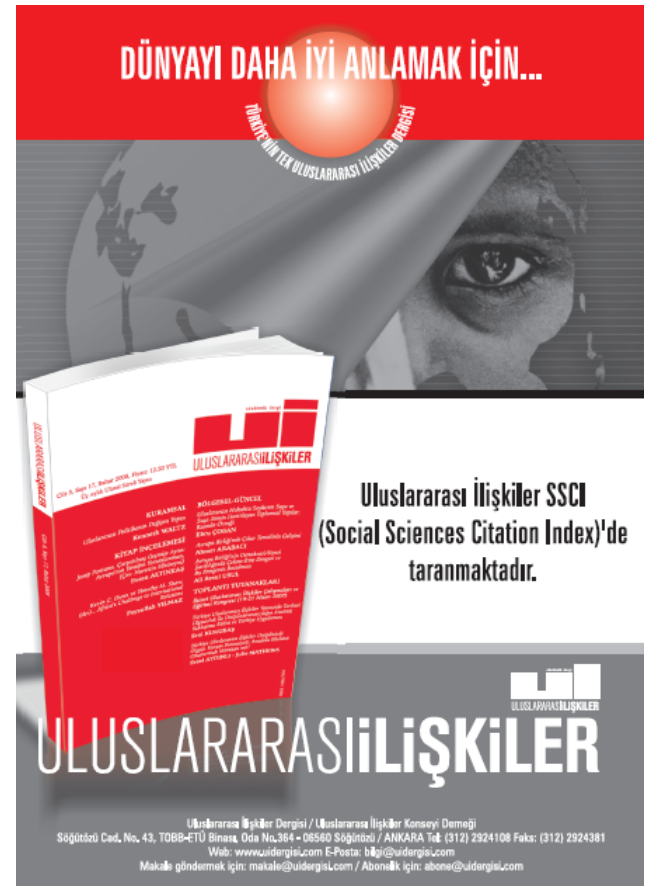

KITAP İNCELEMESI

Thierry CAMOUS, Doğular/Batılar Yirmi Beş Asırlık Savaş

Yener Kutsal YENILMEZ

Doktora Öğrencisi, Galatasaray Üniversitesi, Uluslararası İlişkiler Bölümü

Bu makalenin tüm hakları Uluslararası İlişkiler Konseyi Derneği’ne aittir. Önceden yazılı izin alınmadan hiç bir iletişim, kopyalama ya da yayın sistemi kullanılarak yeniden yayımlanamaz, çoğaltılamaz, dağıtılamaz, satılamaz veya herhangi bir şekilde kamunun ücretli/ücretsiz kullanımına sunulamaz. Akademik ve haber amaçlı kısa alıntılar bu kuralın dışındadır.

Aksi belirtilmediği sürece Uluslararası Illişkiler'de yayınlanan yazılarda belirtilen fikirler yalnızca yazarına/yazarlarına aittir. UIKK Derneğini, editörleri ve diğer yazarları bağlamaz. 


\title{
Doğular/Batılar Yirmi Beş Asırlık Savaş
}

\section{Thierry CAMOUS}

\author{
Hande Güreli (Çev.), Bilge Kültür Sanat, İstanbul, 2011.
}

\section{Hazırlayan: Yener Kutsal YENİLMEZ*}

Fransız tarihçi ve araştırmacı Thierry Camous'nun "Doğular Batılar Yirmi Beş Asırlık Savaş" başlıklı kitabı doğu ve batı olarak ayrıştırılan iki farklı medeniyetin mücadelesini, birbirleriyle yapmış oldukları savaşlar üzerinden ele alan kapsamlı bir çalışmadır. Camous, çalı̧̧masında Doğu ve Batı uygarlıkları arasındaki mücadelenin din savaşları ya da İslam-Batılar bağlamında değerlendiren yaklaşımları sorgulayarak Samuel Huntington'un ünlü "medeniyetler çatışması paradigması"nı eleştirmektedir. Yazara göre, "Doğular" (Orients) ve "Batılar" (Occidents) arasındaki savaşlar sadece din savaşlarına indirgenemez. Bu mücadele, 2500 yıllık bir zaman dilimine yayılarak sanat, bilim ve düşünce tarzlarını da kapsamaktadır. Çalışmasını beş ana bölüme ayıran yazar, Doğular ve Batılar arasındaki mücadeleyi kendine özgü bir şablon uygulayarak anlatmaktadır.

İlk bölümde, Batıları temsil eden eski Yunan-Roma uygarllğıyken Doğuların temsilcisi Perslerdir. Tarafların, savaş alanındaki yansıması özgür birey ile hükümdarın kullarıdır: Bir tarafta vatandaş olan ve birbirleriyle eşit iliş̧kiler içerisinde olan Yunanlılar, diğer tarafta egemen olduğu ülkelerden farklı halkları bir araya getirerek onları savaş alanına sürükleyen Persler. Her iki kültürün farklılığı, kendisini savaş alanında da gösterir. Nicel eksiklikleri, Yunanlıları omuz omuza savaşmaya, birbirlerini kollamaya yöneltmiştir. Savaşları minimum kayıpla atlatma çabası, tüm savaşçların birbirine kenetlendiği ve makine gibi bir bütünlük taşıyan Falanks sisteminin ortaya çıkmasına neden olmuştur. Yunan savaşçısı vatandaşlardan oluşur, ağır silahlıdır ve bu silahlarını kendisi temin eder. Buna karşılık Perslerin, Doğuların, sahip oldukları muazzam insan gücü, kayıpların kolaylıkla telafi edilebilmesini sağlar. Doğular, savaş alanında seri manevralar yapmalarını sağlayan atlara ve uzaktan savaşma gücünü veren okçuluk yeteneğine sahiptir. Fakat koruyucu savaş teçhizatlarının yetersizliği onları yakın dövüşten caydırır. Camous, tüm bu farklılıkları sırasıyla, Perslerin Yunanistan'1 istilası, İskender' in Doğu seferi ve Romalıların Partlar karşısında almış oldukları Carrhae bozgununa değinerek anlatmaktadır.

Birinci bölümde bahsedilen iki taraf arasındaki keskin farkliliklar sonraki dört evrede de benzer şekilde işlenmektedir. Kitabın ikinci uğrak noktası, yerleşik Batılar ile göçebe Doğulardır. Hiç kuşkusuz savaş tarihinde en önemli rol, yirminci yüzyılın ortalarına dek atlarındır. Bir ulaşım aracı olarak yüzyıllar boyunca insanların yer değiştirmesini sağlayan atlar, aynı zamanda savaşçıların da en önemli yardımcısı olmuştur. Tabiri caizse savaş kültürü atlarla şekillenmiştir. At, Avrasya steplerinden Çin, Batı Avrupa, Ortadoğu

\footnotetext{
* Doktora öğrencisi, Uluslararası İlişkiler Bölümü, Galatasaray Üniversitesi, İstanbul. 
ve Hindistan gibi yerlere sarkan göçebe kavimlerin yaşamları için bir vazgeçilmezdir. Kitapta, Roma İmparatorluğu'nun enkazından, çalkantılı bir döneme geçiş yapan Avrupa'ya, bu göçebe kavimlerin yapmış olduğu müdahaleler Hun, Macar, Moğol ve Sarazen atlılarının ekseninde anlatılır. Tanrı'nın kırbacı Atilla, Avrupa'nın korkulu rüyasıdır. Sekizinci ve onuncu yüzyıllar arasında etkin olan Macar atlıların akınları uzun bir süre Avrupalıları dehşete düşürmüştür. 13. yüzyılda Orta Avrupa'da at süren Moğolların, Müslüman dünyaya yaşattıkları trajik akıbetin bir benzerini Avrupa'ya da yaşatmalarını engelleyense büyük kağanlarının ölmesiyle geri dönmek zorunda kalmalarıdır. Sarazenler ise yeni bir dinin getirmiş olduğu coşku ve kararll1ıkla sayılarının azlığına rağmen kısa bir sürede Vizigot İspanyasını ele geçirmeyi başarmışlardır. Batı Avrupa'nın yerleşik halkı, Germen savaşçlığın mirasıyla da tüm bu göçebe saldırganlığa direnmiştir. Atilla’ya karşı verilen Katalan ovası savaşı, Moğollara Doğu Avrupa steplerini sunan Halka Savaşı, Sarazenleri İber yarımadasında tutan Puvatya savaşı, Macar atlıların dehşetinden Avrupalı köylüleri kurtaran Lechfeld Savaşı bu bölümde anlatılan başlıca savaşlardır.

Kitabın üçüncü bölümünde, medeniyetler çatışması denildiğinde akla ilk gelen dinler savaşı konu edilmektedir. On birinci yüzyılın ortalarında "imansızlara karşı savaşırken ölen bir savaşçının günahlarının bağı̧̧lanacağı” fikrinin ortaya çıkması ve Papanın çağrısı, yüz binlerce Avrupalı Hıristiyan'ın din uğruna kutsal topraklara taşınmasına ve Müslümanlarla savaşmasına neden olmuştur. Haçlı seferlerinin hemen herkesçe bilinen bu coğrafi hedefine, Camous iki tanesini daha ekler: İlki, Reconquista (İspanya’nın Hıristiyanlarca Müslümanlardan geri alınması), ikincisiyse Töton şövalyelerinin Doğu Avrupa paganlarına karşı giriştiği (bugünkü Baltık ülkelerini ve Rusya'nın doğusunu kapsayan ve yüzbinlerce insanın katledilmesiyle sonuçlanan) Haçlı seferleridir. Bu seferlerin başlangıcında, Batılar dikkat çekici bir askeri üstünlüğe sahipken, ilerleyen dönemlerde Doğular üstünlügü ele geçirmişlerdir. Töton Şövalyeleri Ruslara yenilirken, Haçliların gücü ise Hattin'de Selahaddin tarafından kırılmıştır. Dini fanatizm yalnız düşmanlarına değil, Doğu Avrupa steplerinde çamura, Suriye çöllerinde ise susuzluğa yenilmiştir. Haçlı fanatizminin zafer kazandığı tek istisna ise İspanya’nın geri alınışıdır. Camous, İspanyadaki bu zaferin, Batıların ordularında değil, Doğuların kendi içlerindeki parçalanmışlıklarında aranması gerektiğini vurgular.

"Rus’u kazıyın altından Tatar çıkar" : Bu söz Avrupalıların Rusları asla içlerinde görmek istemediklerinin, onları ötekileştirdiklerinin bir ifadesi olarak kitabın dördüncü kısmında yer alır. Bu kez söz konusu olan, Batıların uygarlıklarına karşı Doğuların despotik Rus ve Türk imparatorluklarıdır. Ruslar, on sekizinci yüzyılın başında İsveç kralı XII. Karl'nn, on dokuzuncu yüzyıl başında Napolyon ve müttefiklerinin, yirminci yüzyılın ortasında da bu kez Hitler’in ülkelerini istilaya kalkışmalarını ünlü soğuklarının da yardımıyla bertaraf etmeyi başarmışlardır. Tüm bu zaferlerde soğuğun yanı sıra Rusların en önemli kozu, kalabalık kitleleri savaş alanına sürebilme güçleri olmuştur. Kusursuz askeri sistemleriyle Avrupa içlerine kadar ilerleyen Türkler ise önce İnebahtı'da almış oldukları deniz yenilgisiyle Akdeniz'deki güçlerini yitirmişler; asıl darbeyi ise on yedinci yüzyılın sonunda Viyana önlerinde yaşadıkları ağır bozgunla almışlardır. Bu dönemde, Doğuların düşmanlarına karşı en korkutucu askeri güçleri Kazaklar ve Osmanlı Yeniçerileri olmuştur. 
Batılar ve Doğuların kitaptaki son karşılaşması Kuzey-Güney arasındadır: Arapİsrail savaşları, Körfez Savaşları, Usame Bin Laden ve Afganistan. Taraflar arasındaki asimetri, intihar eylemleri gibi yeni ve "ucuz" silahları doğurması açısından dikkat çekicidir. Doğuların bağrındaki Batılı olan İsrail, nüfusunun azlığını ve kuşatılmışlık hissini savaşlarını ani ve direkt - tıpkı Eski Yunanlar gibi - yaparak dengelemektedir. Tüm diğer Batı örneklerinde olduğu gibi kusursuz bir savaş makinesine dönüşme ve ona yatırım yapma gücüne karşı, Doğuların kendine özgü direnme yöntemleri geliştirmesi de kaçınılmazd. Batıl1 "özgür” bireyin algilayamayacağı toplumuna, dinine, kültürüne adanmışlğın ifadesi olarak "kamikaze" saldırıları bu direnişin silahlarıydı. Küresel bir eylem şebekesi olan Usame Bin Laden’in El Kaidesi bu yeni silahı sıklıkla kullanmaktan çekinmeyecektir.

Camous'nun medeniyetler çatışmasını savaş tarihi üzerinden yeniden kurguladığı bu kitap, doğular ve batıların kendi içinde benzeşen farklı savaş kültürlerini yansıtması açısından önemli bir eserdir. Doğular ve Batılar, sadece coğrafi bir alana ya da basit kültürel kodlara indirgenemeyecek karmaşıklıklar içeren bir karşıtlıktır. Çeviri çalışmalarında belirli hatalar dikkatleri çekse de, geniş bir alana yayılan titiz bir çalışmanın ürünü olan "Doğular Batılar", zengin kaynakçasıyla da savaş tarihi ile ilgilenen araştırmacıların ve okurların ilgisini çekecek önemli bir başvuru kaynağı olarak değerlendirilebilir. 